\title{
THE RELEASE OF LH AT OESTRUS IN EWES ON TWO PLANES OF NUTRITION DURING LACTATION
}

\author{
A. W. LISHMAN, W. J. STIELAU, I. E. DREOSTI, \\ W. A. BOTHA, A. M. STEWART AND C. E. SWART \\ Departments of Animal Science and Biochemistry, \\ University of Natal, Pietermaritzburg, South Africa
}

(Received 7th May 1974)

The anoestrous condition which follows upon periods of underfeeding in ewes is apparently similar to the normal seasonal anoestrus and is usually manifested as a prolongation (Hunter, 1962) or precipitated onset (Smith, 1962) of the seasonal period of sexual rest. It has been suggested that the ovarian quiescence noted in underfed animals may be the result of pseudohypophysectomy (Mulinos \& Pomerantz, 1940; Lamming, 1966; Leathem, 1966).

An acute release of $\mathrm{LH}$ at oestrus in ewes has been demonstrated by Niswender, Roche, Foster \& Midgley, 1968; Goding, Gatt, Brown, Kaltenbach, Cumming \& Mole, 1969; Wheatley \& Radford, 1969) and it is possible that changes in the pattern of LH release may indicate functional changes in the pituitary of ewes which become anoestrous after periods of inanition. This phenomenon was studied in an attempt to elucidate the mechanism involved in a premature cessation of breeding amongst ewes previously subjected to underfeeding.

During August, September and October 1970 and 1971 and in October 1972, blood samples were obtained at oestrus from eighty-seven Merino ewes that had been fed either $100 \%$ (high plane) or $50 \%$ (low plane) of their estimated daily nutrient requirements during the preceding 84-day autumn lactation period. The experimental rations, changes in body mass and oestrous activity of the ewes have been described elsewhere (Lishman, Stielau \& Botha, 1974). Jugular blood samples were obtained (indwelling cannulae) from at least five ewes, on each plane of nutrition, which exhibited oestrus after the commencement of a sampling period (i.e. August, September or October 1970 and 1971). The blood samples were taken at 2-hr (1970) or 1-hr (1971), intervals, commencing as soon as a ewe stood for service and sampling continued for up to $36 \mathrm{hr}$. During October 1972, the first blood was drawn approximately $12 \mathrm{hr}$ before the expected onset of oestrus in thirteen ewes. Sampling was repeated at 4-hr intervals until mating commenced and thereafter at hourly intervals for $24 \mathrm{hr}$. A total of ninety-two oestrous periods were studied. In order to detect oestrus, vasectomized rams were placed with the ewes at intervals of not more than $2 \mathrm{hr}$, and the rams were frequently interchanged between various groups of ewes. As soon as a ewe permitted service, she was immediately removed from the presence of the ram.

The double antibody radioimmunoassay for ovine $\mathrm{LH}$, as described by 


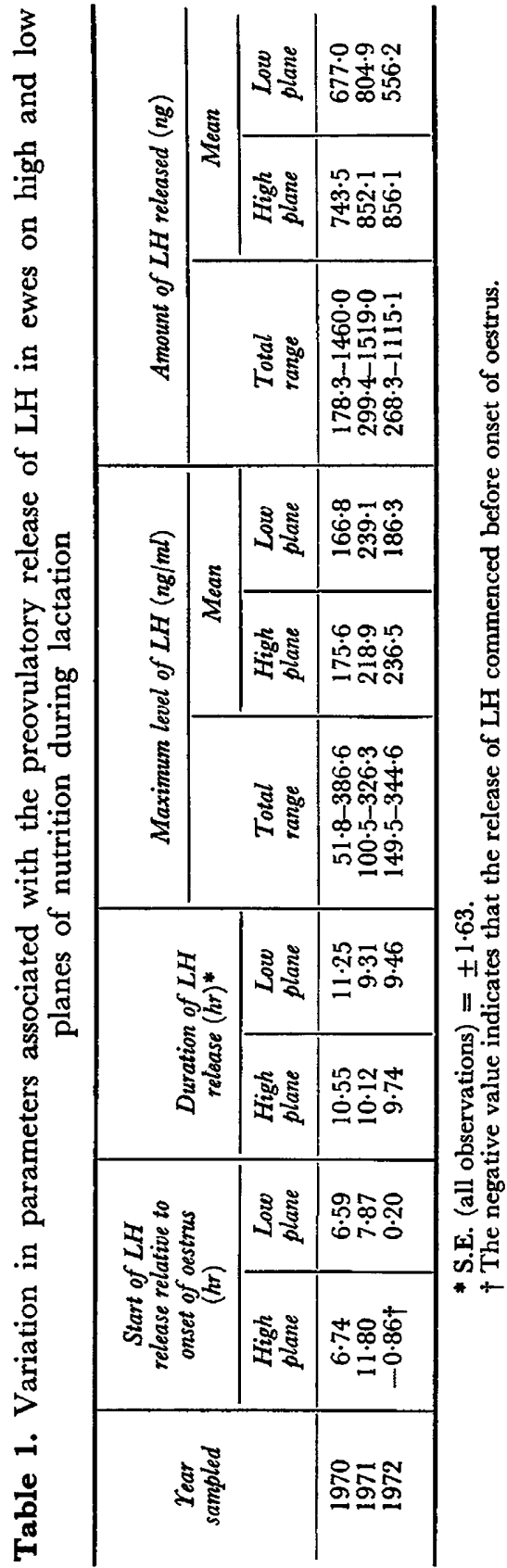


Niswender, Reichert, Midgley \& Nalbandov (1969), was used to quantify LH levels in the plasma samples. As standard, NIH-LH-S16 was used and the initial dilution of anti-LH serum (Lishman, Stielau, Dreosti \& Stewart, 1973) was 1:100,000. The duration of the LH surge (plasma levels equal to or greater than $10 \mathrm{ng} / \mathrm{ml}$ ) was determined graphically, and the total quantity of LH released was estimated as the area under the curve.

The nature of the preovulatory LH release varied greatly (Table 1), and the quantity of LH released ranged between 178.3 and $1519.0 \mathrm{ng}$-more than an eightfold variation. Goding et al. (1969) reported a less than twofold variation in the magnitude of the LH surge, but Reeves, Arimura, Schally, Kragt, Beck \& Casey (1972) noted considerable variation in the amount of LH released as well as in the shape of the release curve following administration of releasing hormones.

Goding et al. (1969) and Wheatley \& Radford (1969) suggested that the LH surge which resulted in ovulation in the ewe did not commence before the onset of mating. This agreed with the time of $\mathrm{LH}$ release from the pituitary as observed by Robertson \& Rakha (1966). The results obtained here, however, indicated that there was a marked variation in the timing of the LH peak in relation to the onset of overt oestrus and that in twenty-two oestrous periods $(23.9 \%)$, it commenced at or before the onset of overt oestrus. Notable variations in the release of pituitary LH in relation to the initiation of mating have also been demonstrated by the earlier studies incorporating bioassay techniques (Santolucito, Clegg \& Cole, 1960; Robertson \& Hutchinson, 1962; Dierschke \& Clegg, 1968).

There was no significant effect of either the plane of nutrition or the year of study on the latency to LH release (Table 1). The log transformation was applied to the data in Table 1 (duration of $\mathrm{LH}$ release excluded), but no significant differences were evident when comparisons were restricted to individual years.

In heifers, it has been concluded that underfeeding results in an increase in plasma LH (Gombe \& Hansel, 1973), a result which is the reverse of the trend suggested by the present results. Gombe \& Hansel (1973) proposed that a restricted intake of energy reduces the responsiveness of the ovary to $\mathrm{LH}$ and this finding has been confirmed by Lishman, Stielau, Swart \& Botha (1974).

The occurrence of oestrus, without an $\mathrm{LH}$ release being detected, was highest during mid- to late anoestrus with a total of twelve (13.0\%) oestrous periods in which no $\mathrm{LH}$ surge was observed during the sampling period. Previously, it had been assumed that when no LH surge was detected at oestrus, this was due to infrequent sampling (Goding et al., 1969; Niswender et al., 1968). Frequent sampling for $24 \mathrm{hr}$ before and $48 \mathrm{hr}$ after oestrus should exclude the possibility of non-detection of LH peaks.

The LH surges recorded at the last oestrus of the one breeding season or at the first oestrus of the new season did not differ distinctly in any respect from those observed in ewes which exhibited regular oestrus throughout the anoestrous season. Further, it was not possible to correlate the pattern of $\mathrm{LH}$ release with the body mass or with a change in the body mass of the ewes during lactation. 
Thanks are due to Dr H. Papkoff and to the National Institute of Arthritis and Metabolic Disease for the kind donation of purified ovine LH. Mr S. Minnaar gave valuable assistance in compiling the computer programmes used.

\section{REFERENGES}

Dierschke, D. J. \& Glegg, M. T. (1968) Studies on the relationship of serum and pituitary gonadotrophin levels to ovulation in the ewe. $\mathcal{F}$. Reprod. Fert. 15, 321.

Goding, J. R., Gatt, K. J., Brown, J. M., Kaltenbach, G. G., Gumming, I. A. \& Mole, B. J. (1969) Radioimmunoassay for ovine luteinizing hormone. Secretion of luteinizing hormone during estrus and following estrogen administration in the sheep. Endocrinology, 85, 133.

Gombe, S. \& Hansel, W. (1973) Plasma luteinizing hormone (LH) and progesterone levels in heifers on restricted energy intakes. F. Anim. Sci. 37, 728.

Hunter, G. L. (1962) Observations on oestrus in Merinos. Proc. S. Afr. Soc. Anim. Prod. 1, 67.

Lamming, G. E. (1966) Nutrition and the endocrine system. Nutr. Abstr. Rev. 36, 1.

Leathem, J. H. (1966) Nutritional effects on hormone production. F. Anim. Sci. 25, Suppl. 1, 68.

Lishman, A. W., Stielau, W. J. \& Botha, W. A. (1974) Reproduction in the ewe in relation to plane of nutrition, bodymass and change in bodymass. I. The incidence of oestrus between lambing and reconception. Agroanimalia, 6, 25.

Lishman, A. W., Stielau, W. J., Dreosti, I. E. \& Stewart, A. M. (1973) Radioimmunological evaluation of rabbit anti-sera to ovine luteinizing hormone. S. Afr. F. Anim. Sci. 3, 67.

Lishman, A. W., Stielau, W. J., Swart, G. E. \& Botha, W. A. (1974) Nutrition of the ewe and the ovarian sensitivity to gonadotrophin. Agroanimalia, 6, 7.

Mulinos, M. G. \& Pomerantz, L. (1940) "Pseudohypophysectomy". A condition resembling hypophysectomy produced by malnutrition. J. Nutr. 19, 493.

Niswender, G. D., Reichert, L. E., Midgley, A. R. \& Nalbondov, A. V. (1969) Radioimmunoassay for bovine and ovine luteinizing hormone. Endocrinology, 84, 1166.

Niswender, G. D., Roche, J. F., Foster, D. L. \& Midgley, A. R. (1968) Radioimmunoassay of serum levels of luteinizing hormone during the cycle and early pregnancy in ewes. Proc. Soc. exp. Biol. Med. 129, 901.

Reeves, J. J., Arimura, A., Schally, A. V., Kragt, G. L., Beck, T. W. \& Casey, J. M. (1972) Effects of synthetic luteinizing hormone-releasing hormone/follicle stimulating hormone-releasing hormone (LH-RH/FSH-RH) on serum LH, serum FSH and ovulation in anestrous ewes. 7. Anim. Sci. 35, 84.

Robertson, H. A. \& Hutchinson, J. S. M. (1962) The levels of FSH and LH in the pituitary of the ewe in relation to follicular growth and ovulation. F. Endocr. 24, 143.

Robertson, H. A. \& RAKHA, A. M. (1966) The sequence, time and duration of the release of folliclestimulating hormone and luteinizing hormone in relation to oestrus and to ovulation in the sheep. F. Endocr. 35, 177.

Santoluctio, J. A., ClegG, M. T. \& Cole, H. H. (1960) Pituitary gonadotrophins in the ewe at different stages of the oestrous cycle. Endocrinology, 66, 273.

Sмiтн, I. D. (1962) The effect of plane of nutrition on the incidence of oestrus in the Merino ewe in Queensland. Aust. vet. 7. 38, 338.

WheATLEy, I. S. \& RADFORD, H. M. (1969) Luteinizing hormone secretion during the oestrous cycle of the ewe as determined by radioimmunoassay. $\mathcal{F}$. Reprod. Fert. 19, 211. 